Discussion Paper No. 10-052

\title{
Small is Beautiful -
}

\section{Experimental Evidence of Donors'}

\section{Preferences for Charities}

Sarah Borgloh, Astrid Dannenberg, and Bodo Aretz

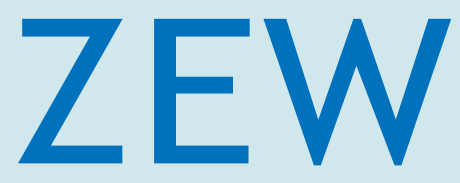

Zentrum für Europäische Wirtschaftsforschung $\mathrm{GmbH}$

Centre for European

Economic Research 
Discussion Paper No. 10-052

\title{
Small is Beautiful - Experimental Evidence of Donors' Preferences for Charities
}

\author{
Sarah Borgloh, Astrid Dannenberg, \\ and Bodo Aretz
}

Download this ZEW Discussion Paper from our ftp server:

ftp://ftp.zew.de/pub/zew-docs/dp/dp10052.pdf

Die Discussion Papers dienen einer möglichst schnellen Verbreitung von neueren Forschungsarbeiten des ZEW. Die Beiträge liegen in alleiniger Verantwortung der Autoren und stellen nicht notwendigerweise die Meinung des ZEW dar.

Discussion Papers are intended to make results of ZEW research promptly available to other economists in order to encourage discussion and suggestions for revisions. The authors are solely responsible for the contents which do not necessarily represent the opinion of the ZEW. 


\section{Non-technical summary}

This paper examines how providing potential donors with information about the revenues of a charity affects charitable contributions. When individuals make a real-life donation decision, they usually do not have precise information about a charity's income streams. They usually do not know whether and how much their neighbors or other people in their social community donate to a certain charity and it is questionable whether they are aware of the exact amount of government subsidies to that charity. They rather have a belief about the charity's size in terms of entire revenues, i.e. whether it is small or large.

With regard to the information about a charity's revenues, various theoretical approaches may be relevant which do not necessarily point in the same direction. Some models assume a positive relationship between past revenues and donations while others suggest a negative relationship. So far, experimental studies have examined either the effect of government contributions or the effect of other private donations on charitable contributions but not the net effect thereof.

Given the empirical nature of the problem and the gap in the experimental literature, we conducted a framed field experiment where a non-student subject pool was asked to make a real donation decision. Half of the subjects could choose whether to give to a charity with relatively low annual revenues or to a charity with relatively high annual revenues. Abstracting from other effects, such as the charities' reputation, our results indicate a negative relation between a charity's entire revenues and private donations to that charity. Our study also provides insights why donors prefer the small organizations and, therefore, discriminates between different theoretical approaches, offering a valuable insight to fundraisers. For most people the lower administrative costs, the higher impact of the own donation, and the neediness of the charity organization are decisive for choosing the small organization. 


\section{Das Wichtigste in Kürze}

Die vorliegende Arbeit untersucht, inwieweit die Größe einer gemeinnützigen Organisation die Bereitschaft, an diese Organisation zu spenden, beeinflusst. Wenn sich Personen in der Realität für oder gegen eine Spende an eine gemeinnützige Organisation entscheiden, wissen sie üblicherweise nicht, wie sich die Einnahmen dieser Organisation genau zusammensetzen. Sie wissen nicht, wie viel ihr Nachbar oder andere Personen aus ihrem sozialen Umfeld an die Organisation spenden oder in welcher Höhe die Organisation staatliche Subventionen erhält. Die Spender haben vielmehr einen Eindruck von der Größe der Organisation in Form ihrer jährlichen Gesamteinnahmen, das heißt sie wissen, ob eine Organisation eher groß oder eher klein ist.

Die verschiedenen theoretischen Ansätze, die für diese Fragestellung relevant sind, deuten nicht alle in die gleiche Richtung. Einige gehen von einem positiven Zusammenhang zwischen Einnahmen einer Organisation und der Bereitschaft, an diese Organisation zu spenden, aus, während andere einen negativen Zusammenhang vermuten. Experimentelle Studien haben bislang entweder nur die Wirkung staatlicher Subventionen oder nur die Wirkung sozialer Information über die privaten Beiträge anderer Spender untersucht, nicht jedoch den Nettoeffekt.

Ziel der vorliegenden Arbeit ist es, diese Lücke zu schließen. Wir haben dazu ein Experiment durchgeführt, in dem nicht-studentische Versuchspersonen eine reale Spendenentscheidung getroffen haben. Die Hälfte der Versuchspersonen konnte sich dabei zwischen einer relativ kleinen Organisation mit geringen Jahreseinnahmen und einer relativ großen Organisation mit hohen Jahreseinnahmen entscheiden. Unsere Resultate zeigen einen negativen Zusammenhang zwischen der Organisationsgröße und der Spendenbereitschaft, wobei wir bewusst von Reputationseffekten abstrahiert haben. Die Studie zeigt außerdem, warum Spender kleine Organisationen bevorzugen. Sie kann damit zwischen verschiedenen theoretischen Ansätzen diskriminieren und liefert wichtige Informationen für die effektive Mitteleinwerbung von Fundraisern. Für die Mehrheit der Spender sind die geringeren Verwaltungsaufwendungen, das höhere Gewicht der eigenen Spende und die Bedürftigkeit der Einrichtung ausschlaggebend für die Wahl der kleinen Organisation. 


\title{
Small is Beautiful - \\ Experimental Evidence of Donors' Preferences for Charities
}

\author{
Sarah Borgloh*, Astrid Dannenberg, Bodo Aretz \\ (ZEW Mannheim)
}

August 2010

\begin{abstract}
:
This paper studies the effect of information about a charity's size on individuals' donations to that charity. We conducted a framed field experiment with a non-student sample, in which subjects had the opportunity to donate for various charitable purposes. The results show that if subjects are to choose between large organizations with high annual revenues and small organizations with low revenues, they prefer the small organizations. We also provide insights why donors prefer the small organizations and discriminate between different theoretical approaches.
\end{abstract}

JEL: H41, C91, D83

Keywords: charitable contributions; information; framed field experiment; fundraising Acknowledgements: The authors would like to thank Bruno Frey, Martin Kocher, Andreas Lange, Susanne Neckermann, Bodo Sturm, Christian Traxler, Joachim Weimann, and Andreas Ziegler for very helpful comments and suggestions. 


\section{Introduction}

When individuals make a real-life donation decision, they usually do not have precise information about a charity's income streams. They do not know whether and how much their neighbors or other people in their social community donate to a certain charity. Furthermore, it is questionable whether they are aware of the exact amount of government subsidies given to that charity. They rather have a belief about the charity's size in terms of entire revenues, i.e. whether it is small or large.

With regard to the information about a charity's revenues, various approaches may be relevant: Theoretical models predict complete or incomplete crowding out of voluntary contributions by government financial support. Furthermore, an impact philanthropist may prefer to give to smaller charities to increase the relative impact of his donation, while the approaches of quality signaling and conditional cooperation predict that larger charities may be chosen more frequently. So far, however, experimental studies have examined either the effect of government financial support on voluntary contributions or the effect of social information on private donations but not the net effect. Experimental evidence hints at incomplete crowding out of private donations by government subsidies, while several studies on social information find a positive relation between others' contributions and those of one's own.

To fill this gap in the literature, we question how providing potential donors with information about the revenues of a charity affects charitable contributions. To this end, we conducted a framed field experiment where a non-student subject pool was asked to make a real donation decision. Half of the subjects could choose whether to give to a charity with relatively low annual revenues or to a charity with relatively high annual revenues. Our study is the first that presents evidence on the net effect and it shows a negative relation between a charity's entire revenues and private donations to that charity.

The outline of the paper is as follows: The second part summarizes the findings of the relevant theoretical and empirical literature and motivates our experimental framework. Part three describes the experimental setting and the fourth part delivers the results of the experiment. Part five concludes. 


\section{Background and Motivation}

In this paper, we study the effect of third-party contributions on individual donations to charitable organizations. Third-party contributions to a charity may stem from governmental subsidies or other individuals' donations, respectively. Theoretical models and empirical studies have looked at the effects of both sources of charities' income on private donations.

The standard public goods model (Warr, 1982, Roberts, 1984, Bergstrom et al., 1986) predicts that private voluntary contributions are completely crowded out by government contributions to the same good. In this model, an individual derives utility from his private consumption as well as the total supply of the public good. If a contributing individual is taxed in order to finance the public good, he decreases his voluntary contributions by exactly the same amount, as long as the taxes to be paid do not exceed the voluntary contribution he made previous to the taxation. It is reasonable, though, to assume that a potential donor also derives positive utility from the mere act of contributing. Andreoni $(1989,1990)$ coined the term 'warm glow' to describe such preferences, where an individual's utility increases with the amount contributed. In this case, government contributions are not a perfect substitute for voluntary contributions, which implies that the former crowd out the latter only incompletely: An individual's contribution decreases by less than the exact amount of government's contributions. ${ }^{1}$

The empirical evidence on the theoretical predictions of crowding out is mixed. In a literature review, Steinberg (1991) concludes crowding out of private charitable contributions by government spending to be between $0.5 \%$ and $35 \%$. Also, more recent studies provide evidence for incomplete crowding out (among others Ribar and Wilhelm, 2002, Gruber and Hungerman, 2007, Andreoni and Payne, 2009). There is, however, also empirical evidence for crowding in of voluntary contributions (Khanna et al., 1995, Khanna and Sandler, 2000, Payne, 2001). Arulampalam et al. (2009) use charity-level data for the special case of UK overseas development charities. They find no crowding-out of donations to development by official development assistance, however their results hint at a modest positive effect of government grants on private giving. This implies that donors may be attracted to charities which receive substantial support from the state.

\footnotetext{
${ }^{1}$ Steinberg (1987) proposes a model of mixed motives in which donations may not necessarily be a normal good. He shows that individuals' contributions may rise or fall in response to an increase in government's contributions. Moreover, Ribar and Wilhelm (2002) show that with impurely altruistic preferences both asymptotically zero and asymptotically complete crowding out may occur.
} 
Furthermore, several laboratory experiments try to test the hypothesis of complete crowding out. Andreoni (1993) compared two groups of subjects that use the same mechanism to provide a public good, but face different levels of government provision. A minimum contribution level of two tokens is meant to resemble a tax which is used to finance a public good. If there was complete crowding out, average contributions (including the two tokens tax) should be the same in both groups. However, the author finds that crowding out is incomplete. Chan et al. (2002) use the same mechanism to confirm the result and extend it by the finding that crowding out increases as the size of the involuntary transfer increases. Bolton and Katok (1998) let subjects play a dictator game and vary the initial endowments of dictators and recipients (from $\$ 15$ for the dictator and $\$ 5$ for the recipient to $\$ 18$ and $\$ 2$, respectively). They find that the proportion of non-givers does not differ across the treatments, but that individuals in the 15-5 treatment give less, so there is some crowding out. Eckel et al. (2005) use the same mechanism, but control for fiscal illusion and the recipients are charities. If there is no fiscal illusion, i.e. the subject knows that the initial allocations are resulting from being taxed, there is support for the theoretical prediction of complete crowding out. In case of fiscal illusion, however, crowding out is zero. Konow (2010) keeps the endowment of the dictator fixed but changes the endowment of the recipient in the subsidy treatment from $\$ 0$ to $\$ 4$ and confirms the result of partial crowding out.

As charities do not only earn income from government contributions, further theoretical approaches have to be taken into account. Duncan's (2004) theory of impact philanthropy relates to individuals who aim at having a distinct effect on the supply of a charitable good, i.e. they want to 'personally make a difference'. Hence, an impact philanthropist may benefit from a charity's lower income. This is because an increase in the revenues of a charity or others' contributions causes negative externalities - the importance and the impact of the philanthropist's donation are reduced. It then may be that an impact philanthropist - if provided with the choice between two charities of different size - chooses to give to the charity with smaller income streams because this increases the relative impact of his gift. ${ }^{2}$ Moreover, an impact philanthropist dislikes financing the administrative costs of a charity. If a philanthropist assumes larger charities to have greater administrative costs, he would prefer to give to the smaller organization. In yet another theoretical model, Andreoni (1998) assumes the existence of a nonconvexity in the production function of the public good, i.e. a minimum

\footnotetext{
${ }^{2}$ The theoretical model suggested by Duncan, however, leads to no clear predictions how a change in the endowment of a charity or in the contributions of others would affect the size of the gift.
} 
threshold that must be met for the public good to be consumed. He shows that in this case others' contributions may be regarded as substitutes for one's own.

On the other hand, however, models have been proposed which suggest that a positive effect of third-party contributions on individuals' donations may prevail. One approach is to model contributions by other individuals as a signal of the charity's quality as Vesterlund (2003) suggests. Typically, donations are not made simultaneously, but rather in a sequential manner, where high donations by other individuals suggest a high-quality charity which may induce individuals to give larger amounts to that organization. Andreoni (2006) remarks that leadership gifts may also be perceived as a signal for the respective charity's quality. To make this signal credible, however, the leadership gift has to be sufficiently high. So, if a charity with higher revenues is perceived to be of a higher quality it should be targeted by donors more likely than a charity with lower revenues. What is more, the phenomenon of conditional cooperation predicts that individuals will be more willing to contribute if they know that others contribute (Fischbacher et al., 2001).

Several natural field experiments investigate how information about others' contributions affects charitable donations. Frey and Meier (2004) present evidence from a large-scale field experiment on conditional cooperation. They find that when students are presented with information that many other fellows donated to certain charitable funds, their willingness to contribute increases. The studies of Croson and Shang (2008; 2009) support this finding. Their setting is an on-air fundraising campaign for a public radio station where another member's contribution is mentioned to participants before they make their own pledge. The results of their field experiment show that (social) information about others' high contributions influences one's own contributions positively. The information effect also works downwardly. When renewing donors are presented with information about another donor's contribution which is either above or below their last year's contribution, respondents adjust their contribution in the direction of the information (Croson and Shang, 2008). Croson and Shang (2010), however, demonstrate a natural limitation of the social information effect. When the social information is too extreme, it may lead to lower individual contributions. Also, Martin and Randal (2008) show that donors positively respond to information about others' contributions. Using field data from an art gallery, they find that depending on the composition of coins and bills in a transparent donation box, the more bills are exhibited relative to coins the lower is the participation rate and the higher is the average donation. While these two opposing effects level off, so that similar total donation amounts are realized 
across these treatments, a displayed donation box which is empty induces lower overall donations. $^{3}$

In summary, previous experimental studies indicate that there is incomplete crowding out of voluntary contributions by government contributions and that providing information about others' contributions increases either the propensity to donate, the size of the donation, or both. Our approach differs from previous experiments in two important aspects. First of all, the information presented to each subject in our experiment consists of two intervals stating the yearly revenues received by an organization which comprises donations, membership fees and public subsidies. We deem this kind of information to be very close to the situation potential donors find themselves in the real world, as they usually cannot distinguish the size of other donors' gifts and may not be aware of the extent to which a charity receives government subsidies. The information is provided to distinguish charities by their size. Donations to larger organizations could mirror the fact that charities' revenues serve as a signal for good quality of a charity whereas donations to smaller organizations might reflect crowding out at the organization level or the aim at having a higher relative impact through the donation. Our framework however, is not meant to test for crowding out of voluntary contributions to a certain public good, e.g. development aid. If a subject chooses to give to a small development organization instead of the large one, he still consumes the public good. Hence, crowding out rather happens on the organizational level.

Secondly, we use a framed field experiment rather than a natural field experiment. Unlike in a natural field experiment, subjects in a framed field experiment undertake the task in an artificial environment and know that they are part of an experiment (Harrison and List, 2004). Although this may bias the subjects' behavior to some extent, we can make use of the advantages of framed field experiments in terms of more control and the elicitation of personal characteristics of our participants. In addition, we can exploit that the donation decisions are made completely anonymously in our setting. In door-to-door-fundraising, solicitation letter campaigns or other kinds of donation campaigns the identity of the donor is usually known to the organization. By means of our double-blind procedure however, neither other experimental subjects nor the experimenter know the amount of the donation made by a certain donor. This enables us to rule out an experimenter effect or certain motivations such as signaling of wealth, prestige or social approval. That such social incentive effects can arise

\footnotetext{
${ }^{3}$ The experimental literature on seed money may also be used to study the effect of information on charitable giving. In seed money experiments, it is announced that some particular amount has already been collected or provided by an anonymous donor or institution. List and Lucking-Reiley (2002), Landry et al. (2006), and Rondeau and List (2008) all find a positive effect of seed money on individual donations.
} 
from removing anonymity is shown in the field (Soetevent, 2005) as well as in the lab (Hoffman et al. 1994; Andreoni and Petrie, 2004).

Furthermore, framed field experiments are characterized by a non-student subject pool and field context in the commodity and therefore offer more realism than conventional lab experiments (Harrison and List, 2004). A weakness of lab experiments is often seen in the weak representativeness of the sample and thus the lacking generalizability of results. Especially in the case of donation decisions representativeness might be important. Carpenter et al. (2008) for example show in a laboratory experiment that students tend to be less likely to donate to a charity than members from the broader community.

\section{Experimental Design}

\subsection{Implementation and Participants}

For subject recruitment, invitation letters were randomly distributed in the city of Mannheim, Germany (see Appendix C). The letter contained an invitation to take part in a scientific study and informed people that they would receive $€ 40$ for participation. It was announced that there would be a kind of survey in which they could (voluntarily and anonymously) make consumption decisions. We used a relatively high show-up fee in order to avoid underrepresentation of people with high opportunity costs of time. Furthermore, we already emphasized in the invitation letter that the money was a reward for participation in the study in order to make people feel entitled to their endowment and to avoid a bias due to unexpected gift money. The experiment took place in July 2009 on the premises of the Centre for European Economic Research (ZEW) in Mannheim. A total of 223 participants took part in the experiment. At the beginning of each session, participants individually drew lots to determine their ID number (which remained unknown to other participants and the experimenters) and chose a table. The tables had privacy screens on every side to ensure private decisions and answers. Participants were not allowed to talk to each other. If they had questions, the experimenters answered them privately. The 12 experimental sessions lasted around 60 minutes each. Within one session, all subjects performed exactly the same task. At first, all participants obtained detailed instructions about the course of the experiment (see Appendix B). The main features were orally repeated. We emphasized that all information given in the instructions was true. Participants in all treatments filled out a questionnaire with questions about socio-demographic characteristics, their donation habits, and their attitude toward their own social standing within society and toward governmental responsibilities. The 
attitudinal questions were taken from the German General Social Survey (ALLBUS) which is conducted every two years with a representative sample of the German population. ${ }^{4}$ At the end of each session, participants had the chance to comment on the experiment and to give reasons for their decisions (see Figure A1 in Appendix A for a detailed overview of the experimental proceedings).

Participants' socio-demographic characteristics are shown in Appendix A (Tables A1 and A2). The subject pool is highly diversified with for example age ranging from 18 to 75 years. Although it is not fully representative of the German resident population, it is sufficiently diversified in all socio-demographic variables in order to examine the influence of each variable on charitable behavior. Moreover, in case of gender, income, and religion, the distribution of our subject pool does not significantly differ from that of the German population (chi squared test, t-test, $\mathrm{p}>0.1)^{5}$. More precisely, $46.2 \%$ of subjects are male. $22.9 \%$ dispose of a monthly net household income of less than $€ 1,000$, most of the subjects live in households with incomes between $€ 1,000$ and $€ 3,000$ and only $13.0 \%$ have more than $€ 3,000$ per month disposable. With regard to religion, Catholics (31.4\%) and Protestants $(31.8 \%)$ are equally represented, whereas $6.7 \%$ possess another religious affiliation and $30.0 \%$ of all subjects do not belong to any religious community. Participants' responses to questions regarding their giving behavior in the past as well as their attitudes are also displayed in Appendix A (Tables A3 and A4).

\subsection{Treatments}

The experiment comprised two treatments which both contained a real donation stage where subjects simultaneously and independently decided how much (if any) of their endowment to donate to a certain charity. Subjects were informed that all of the selected charities have obtained the 'DZI Spendensiegel', a label for charities that use their funds economically and according to their statutes. ${ }^{6}$ Subjects could choose one of four charitable causes, namely disabled care, development aid, medical research, and animal protection, whereby subjects knew only the purpose but not the name of the organizations to avoid any reputation effects. All donation decisions were completely voluntary and anonymous. We used a double-blind procedure in which neither other subjects nor experimenters came to know if, how much and to which cause a subject donated. Subjects received a large envelope containing two small

\footnotetext{
${ }^{4}$ For detailed information, see http://www.gesis.org/en/services/data/survey-data/allbus/.

${ }^{5}$ Unless stated otherwise, all tests in this paper are two-sided.
} 
envelopes and the endowment of $€ 40$ broken into two 10 -euro notes, one 5-euro note, six 2euro coins, and three 1-euro coins. This breakdown enabled subjects to donate any integer amount between $€ 0$ and $€ 40$ and abated incentives to only give the coins. Subjects placed the amount they wished to donate in one of the small envelopes assigned to donations, labeled the envelope with their ID number and, in case they were willing to give a positive amount, the charitable cause to which they wished to donate. The amount of money subjects wished to keep for themselves was placed in the other small envelope. Afterwards, subjects dropped the sealed envelope specified for donations in a box.

The baseline treatment ("NoInfo") with 113 subjects involved the above described donation stage and afterwards the completion of the questionnaire. The 110 subjects in the treatment "Info" were informed not only about the charitable cause of the organizations but also about their revenues taken by donations, membership fees and public subsidies in 2006. For each charitable cause, we offered two organizations, one relatively small organization with revenues between $€ 40,000$ and $€ 300,000$ and one relatively large organization with revenues between $€ 5$ million and $€ 11$ million. Thus, subjects in this treatment could choose one of eight organizations for their donation. All donations made during the experiment were transferred in full to the respective organizations. In case of the NoInfo treatment, donations were equally assigned to small and large organizations of the same cause. The counting of donations and the transfer to the organizations were notarially monitored and certified. This procedure and the name of the notary were already announced in the experimental instructions. ${ }^{7}$

\section{Results}

\subsection{Univariate analysis}

In total, $€ 1,225$ are donated to the charities. Mean donation per participant is $€ 5.49$ or $13.7 \%$ of the endowment, median donation is $€ 3.00$. Broken down by purposes, $€ 448$ are donated to disabled care, $€ 318$ to development aid, $€ 274$ to medical research, and $€ 185$ to animal protection. Disabled care is not only the purpose which is selected most frequently (21\%) but which also receives the highest average donations (9.53€). Whereas individual donations do not differ significantly between the four purposes, subjects select animal protection less frequently than the other three purposes (binomial test $1 \%$ significance). Overall, $33 \%$ of the

\footnotetext{
${ }^{6}$ For more information (in German language), see www.dzi.de.

${ }^{7}$ Some participants also completed another task (a dictator game) in the experiment which is not part of this paper. As this task did not affect the donation decision, we pooled the data.
} 
subjects do not make a donation at all. Table 1 contains the descriptive statistics of the donation distribution.

Table 1: Descriptive statistics

\begin{tabular}{lllll}
\hline & Observations & Share in $\%$ & $\begin{array}{l}\text { Total donation } \\
\text { (in } € \text { ) }\end{array}$ & $\begin{array}{l}\text { Average donation } \\
\text { (in } € \text { ) }\end{array}$ \\
\hline No donation & 74 & 33 & 0 & 0 \\
Donation & 149 & 67 & 1,225 & 8.22 \\
$\quad$ Disabled care & 47 & 21 & 448 & 9.53 \\
Development aid & 39 & 17 & 318 & 8.15 \\
Medical research & 38 & 17 & 274 & 7.21 \\
Animal protection & 25 & 11 & 185 & 7.40 \\
\hline Total & 223 & 100 & 1,225 & 5.49 \\
\hline
\end{tabular}

In the NoInfo treatment in which subjects did not obtain information about charity revenues, mean donation per participant is $€ 5.56$ and in the Info treatment in which subjects obtain this information, mean donation is $€ 5.43$ (compare Table 2). Interestingly, providing participants with this information neither has an impact on individual donations nor on the probability to select a certain charitable cause. However, it shifts donations within the group of subjects who obtained the information: $€ 455$ are donated to small organizations and $€ 132$ are donated to large organizations. On average, participants donate $€ 8.92$ to small organizations and $€ 6.95$ to large organizations; this difference, however, is not statistically significant.

Table 2: Descriptive statistics - NoInfo versus Info Treatment

\begin{tabular}{cllll}
\hline & Observations & $\begin{array}{l}\text { Share in \% by } \\
\text { treatment }\end{array}$ & $\begin{array}{l}\text { Total donation } \\
\text { (in } € \text { ) }\end{array}$ & $\begin{array}{l}\text { Average donation } \\
\text { (in } € \text { ) }\end{array}$ \\
\hline NoInfo treatment & 113 & 100 & 628 & 5.56 \\
No donation & 35 & 31 & 0 & 0 \\
Donation & 78 & 69 & 628 & 8.05 \\
\hline Info treatment & 110 & 100 & 597 & 5.43 \\
No donation & 39 & 36 & 0 & 0 \\
Small organization & 51 & 46 & 455 & 8.92 \\
Large organization & 19 & 17 & 132 & 6.95 \\
\hline Total & 223 & 100 & 1,225 & 5.49 \\
\hline
\end{tabular}

Out of the 110 subjects who received information and made a positive donation, $73 \%$ choose the small organization, and only $27 \%$ choose the large organization. Thus, the shift of donations occurs mainly because small organizations are selected more frequently than large organizations (binomial test $1 \%$ significance). We observe this effect for all charitable causes (at least 5\% significance each), compare Figure 1. The preference for small organizations appears to be very pronounced in the case of disabled care: Here, $86 \%$ of donors choose the small organization and $14 \%$ choose the large one. In case of development aid (medical research, animal protection), $68 \%(64 \%, 69 \%)$ of donors select the small organization. 
Figure 1: Selection of organization size in the Info treatment [in \% of donors]

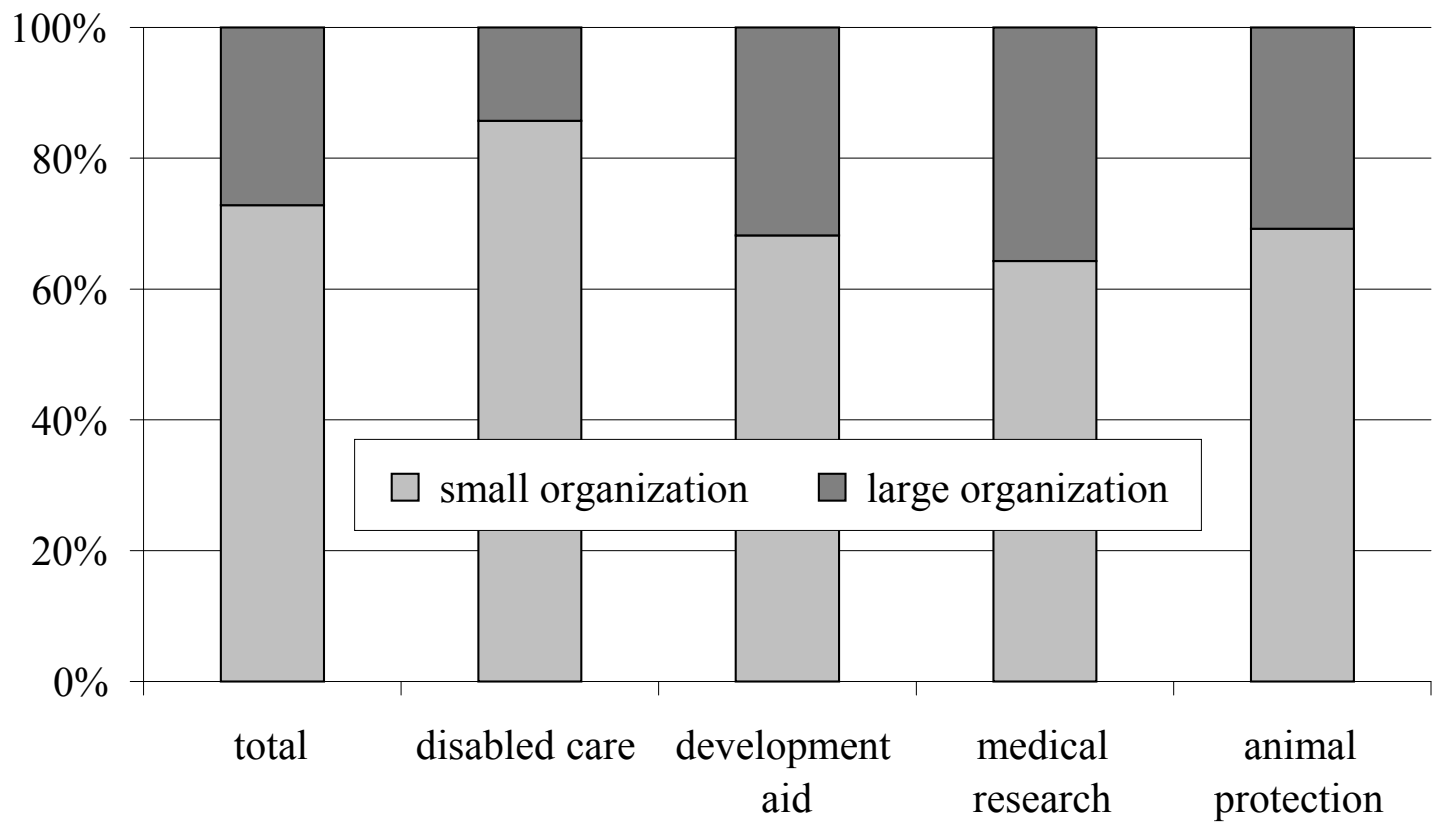

In the theory section we have proposed different explanations why people may prefer small organizations to large ones. However, we cannot be sure whether these reasons actually induced the subjects to choose the small organization. There are several other possible reasons for people's preferences which are not captured by the theoretical models. For example, small organizations might be associated with more local activities.

For this reason, we conducted an ex-post online survey with the subjects who participated in the Info treatment. The survey was completely anonymous and contained questions about the decisions in the experiment, namely (i) whether subjects donated a positive amount, if so (ii) to which charitable cause, (iii) to a small or a large organization, and given that choice (iv) for what reason they chose the small or the large organization. All questions offered predetermined answers including the option "I cannot remember". If participants had chosen the small organization, they were provided with the following answers: "For my decision to donate to the small organization, it was decisive that (a) my donation to the small organization has a higher impact compared to a large organization, (b) small organizations are discriminated against compared to large ones and therefore need more support, (c) small organizations have lower administrative costs compared to large ones and therefore my donation is more likely to benefit the actual charitable cause, (d) small organizations are more likely to act on a local level compared to large ones, (e) small organizations are more specialized in certain fields of activity compared to large ones, (f) other reasons." If participants had chosen the large organization, they were provided with these options: "For 
my decision to donate to the large organization, it was decisive that (a) the large organization was able to already collect many funds (consisting of donations, membership fees and public subsidies), (b) large organizations can achieve more with my donation than the small ones, (c) large organizations have a higher level of familiarity compared to small ones, (d) large organizations are more likely to act professionally compared to small ones, (e) other reasons." In both cases, the predetermined options randomly varied between participants, they could select several options and give further reasons in an open description field.

\section{Figure 2: Reasons to choose the small organization [in \% of donors]}

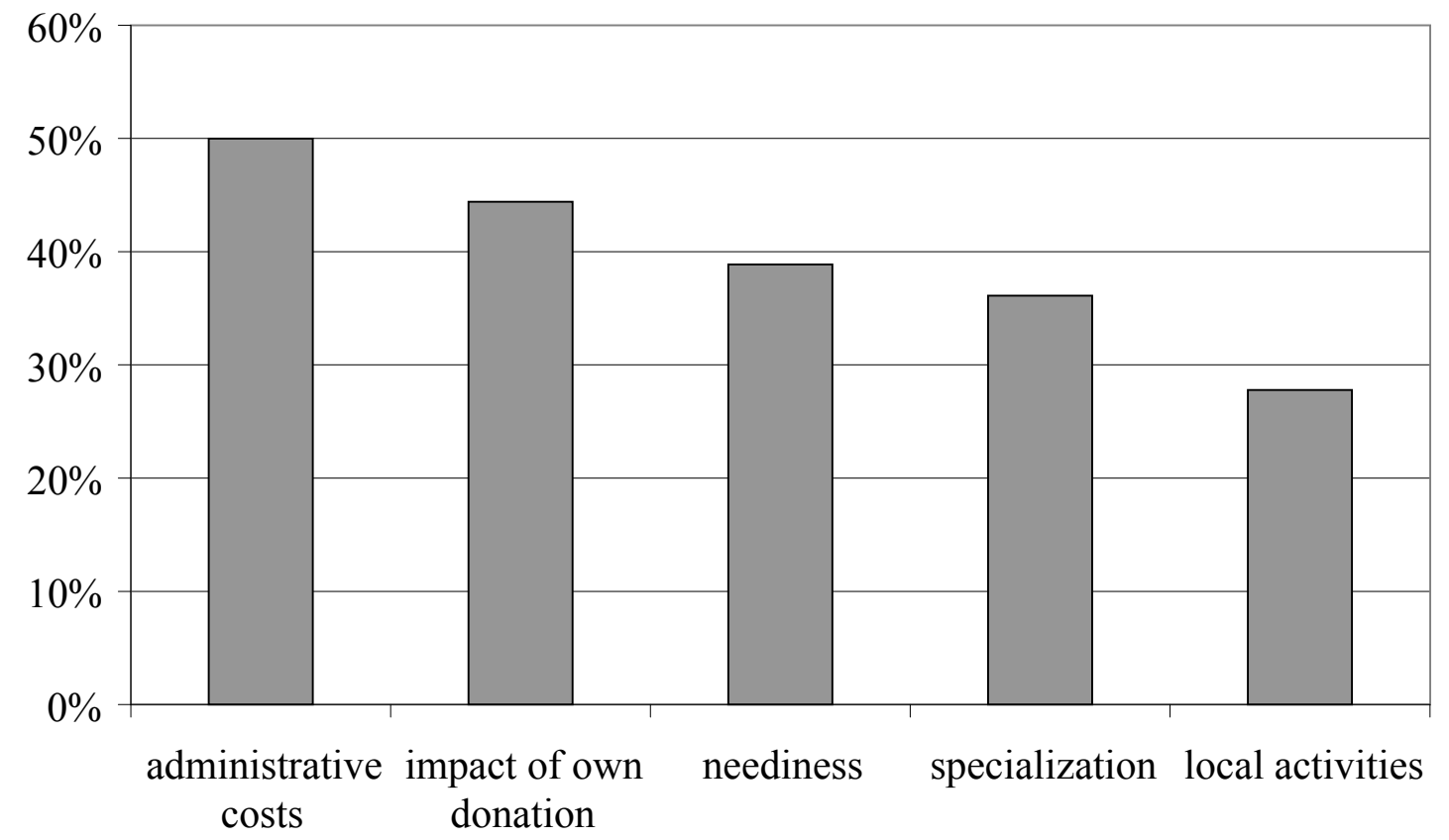

Out of the 104 individuals who were invited to the survey 81 individuals took part. ${ }^{8}$ The statements made in the survey are consistent with the observed behavior in the experiment, i.e. there are no significant differences between the survey data and the experimental data. For example, the $68 \%$ of responders stating in the survey that they donated a positive amount correspond to $64 \%$ who in fact donated a positive amount in the experiment. Let us first consider the people who had chosen the small organization. The reasons for this decision which are mentioned most frequently are lower administrative costs $(50 \%)$ and a possible higher impact of the own donation (44\%). Recall that these are the motives that are captured by the impact theory. Another reason which is mentioned frequently is the neediness of small organizations (39\%), indicating the existence of a crowding out effect at the organizational level (see Figure 2).

\footnotetext{
${ }^{8}$ As an incentive to participate, everyone who completed the survey took part in a drawing for 5 times 30 Euros. A few people completed the survey via mail because they did not provide an email address. Six participants in the Info treatment were not invited to the survey because they did not provide any contact details.
} 
Regarding the choice of the large organization the most frequently stated reason is the professionalism of large organizations (86\%) followed by the achievement of objectives (43\%) and the apparent ability to acquire funds (29\%). All these motivations support the quality signaling approach. However, this signal attracts only few donors.

\subsection{Multivariate analysis}

Besides looking at the effects of the various treatments, we ran econometric estimations to analyze the impact of various socio-demographic variables which have been surveyed in the questionnaire. Around $33 \%$ of the subjects decided not to donate, hence there is a large number of observations clustered at zero donations. In this case, ordinary least squares estimates would not be accurate, so we conduct a maximum likelihood estimation of a Tobit model. In the baseline estimation, we include the following socio-demographic variables: age, household size as the absolute number of household members including children, dummy variables for male subjects, unmarried subjects, subjects not having any religious affiliation (no religion), voters of the left party, highly educated subjects (education, owning a graduate degree), high income subjects (monthly net household income of $2.000 €$ or more).

It is very likely, however, that there are unobservable features influencing the decision whether to make a charitable contribution or not. Therefore, we additionally include four attitudinal variables taken from the German General Social Survey (ALLBUS) to control for one's perceived standing within society and the attitude towards the state. More precisely, the variable position is a dummy variable for subjects thinking they receive their fair share or more compared to others living in Germany. The variable disparities is coded as ' 1 ' for those subjects believing that the social disparities in Germany are just. The variable state resp is a dummy for subjects who want the state to care for a good living in case of illness, misery, unemployment and old age. Similarly, the variable equalize takes the value ' 1 ' if a subject indicated that it is the responsibility of the state to reduce income disparities. Although it is quite common to include attitudinal variables in econometric estimations (e.g. Corneo and Grüner, 2002), the causality between these variables and the dependent variable (donations) may run in both directions, i.e. these variables may be endogenous. For this reason, Table 3 displays both estimations with attitudinal variables and those without these variables in order to show whether effects are robust to this modification. The second specification furthermore includes a dummy variable for subjects that already made a charitable donation in the year 2009 (donor 2009) in order to control for offsetting effects. Furthermore, we ran both 
estimations with and without outliers. Outliers were defined as those subjects contributing more than half their endowment (€20) in the donation decision (five subjects).

Table 3: Tobit estimation results

\begin{tabular}{|c|c|c|c|c|}
\hline \multirow[b]{2}{*}{ Variables } & \multicolumn{2}{|c|}{ Including outlier } & \multicolumn{2}{|c|}{ Excluding outlier } \\
\hline & (1) & (2) & (3) & (4) \\
\hline \multirow[t]{2}{*}{ _cons } & $-11.27 * * *$ & $-9.088 *$ & $-5.904 *$ & -5.685 \\
\hline & $(-2.671)$ & $(-1.931)$ & $(-1.782)$ & $(-1.532)$ \\
\hline \multirow[t]{2}{*}{ age } & $0.232 * * *$ & $0.236 * * *$ & $0.170 * * *$ & $0.183 * * *$ \\
\hline & $(3.760)$ & $(3.780)$ & $(3.461)$ & $(3.648)$ \\
\hline \multirow[t]{2}{*}{ male } & -1.563 & -1.658 & -0.773 & -1.083 \\
\hline & $(-1.094)$ & $(-1.147)$ & $(-0.689)$ & $(-0.950)$ \\
\hline \multirow{2}{*}{ household size } & -0.00620 & -0.125 & -0.298 & -0.461 \\
\hline & $(-0.00738)$ & $(-0.147)$ & $(-0.451)$ & $(-0.686)$ \\
\hline \multirow[t]{2}{*}{ unmarried } & $6.419 * * *$ & $5.893 * * *$ & $4.193 * * *$ & $4.099 * *$ \\
\hline & $(3.201)$ & $(2.939)$ & $(2.646)$ & $(2.572)$ \\
\hline \multirow[t]{2}{*}{ no religion } & -1.279 & -1.200 & $-3.179 * *$ & $-3.120 * *$ \\
\hline & $(-0.812)$ & $(-0.762)$ & $(-2.522)$ & $(-2.457)$ \\
\hline \multirow[t]{2}{*}{ left party } & $-9.109 * * *$ & $-9.315 * * *$ & $-6.822 * * *$ & $-6.611 * * *$ \\
\hline & $(-2.996)$ & $(-2.996)$ & $(-2.899)$ & $(-2.747)$ \\
\hline \multirow{2}{*}{ education } & $3.991 * * *$ & $3.962 * *$ & $2.187 *$ & $2.271 *$ \\
\hline & $(2.622)$ & $(2.593)$ & $(1.834)$ & $(1.890)$ \\
\hline \multirow[t]{2}{*}{ income } & $4.695 * * *$ & $4.614 * * *$ & $3.357 * *$ & $3.353 * *$ \\
\hline & $(2.722)$ & $(2.675)$ & $(2.480)$ & $(2.470)$ \\
\hline \multirow[t]{2}{*}{ donor 2009} & & -2.194 & & -1.369 \\
\hline & & $(-1.333)$ & & $(-1.058)$ \\
\hline \multirow[t]{2}{*}{ position } & & 0.0959 & & -0.301 \\
\hline & & $(0.0621)$ & & $(-0.248)$ \\
\hline \multirow[t]{2}{*}{ disparities } & & 0.988 & & 1.730 \\
\hline & & $(0.605)$ & & $(1.349)$ \\
\hline \multirow[t]{2}{*}{ state resp } & & -2.541 & & -0.212 \\
\hline & & $(-1.411)$ & & $(-0.145)$ \\
\hline \multirow[t]{2}{*}{ equalize } & & 1.100 & & -0.467 \\
\hline & & $(0.748)$ & & $(-0.398)$ \\
\hline No. of observations & 189 & 189 & 184 & 184 \\
\hline LR Chi ${ }^{2}$ & $44.53 * * *$ & $49.09 * * *$ & $39.95 * * *$ & $43.39 * * *$ \\
\hline Pseudo $\mathrm{R}^{2}$ & 0.0418 & 0.0460 & 0.0414 & 0.0450 \\
\hline
\end{tabular}

Notes: t-statistics in parentheses. Estimations (3) and (4) exclude outliers.

Levels of significance: $* 10 \%, * * 5 \%, * * * 1 \%$ significance.

Our results show a positive and highly significant effect of age on charitable donations, whereas the coefficients for male donors and household size are not significant. This finding is robust across all four models. Moreover, across all four estimations, voters of the left party on average give significantly smaller amounts than all other subjects. Surprisingly, being unmarried affects the donation decision positively and significantly. It may be suspected that unmarried subjects, as they may have less responsibility for other people in their everyday life, feel more obliged to help others with their donation.

Subjects without a religious affiliation seem to make significantly lower contributions, but the corresponding coefficient is only significant when outliers are excluded. As expected from previous empirical investigations, high incomes and high education both have a positive 
impact on donations although the significance levels vary according to the estimation specification. The relation between donations in the experiment and donations that have been made in the year 2009 previously to the experiment is as expected negative, though not significant. Furthermore, the attitudinal variables do not have any explanatory power.

We have seen that small organizations are preferred by the donors and certain characteristics influence the donation behavior differently. In a further step we now investigate whether subjects' characteristics differ with respect to the donation choice. As we face three possible outcomes (no donation, donation to a small organization and donation to a large organization), a multinomial response model is appropriate. Since we assume that adding another donation category, e.g. a medium sized organization, affects the donation decision of donors and nondonors differently, the assumption of the irrelevance of independent alternatives does not hold in our case. Therefore, we make use of the nested logit model. In particular, we define two nests in which one nest consists of all non-donors of the Info treatment while the other nest contains all donors that donated to either a small or a large organization. As the base variable we choose the outcome "small organization" as it was selected most frequently by the subjects. We use the same explanatory variables as in the first specification of Table 3 . The earlier defined outliers are included in our analysis as the decision to donate or not to donate is now the major point of interest (rather than the size of the donation). Furthermore, the results do not change if we exclude the outliers.

From Table 4 we see that donors who donate to a small organization do not significantly differ from donors who donate to a large organization (column 2). When comparing the donors to the small organization with the non-donors (column 1), we find that donors to small organizations are more likely to be unmarried than the non-donors $(p<0.1)$. This result confirms the findings we reported earlier in Table $3 .^{9}$

\footnotetext{
${ }^{9}$ We also investigated in how far personal characteristics influence the choice of the charitable cause differently. The results turn out to be insignificant: with help of a nested logit model we find that subjects who donated to disabled care do not have significantly different characteristics compared to people who donate to development aid, medical research or animal protection.
} 


\begin{tabular}{lll}
\hline Variable & $(1)$ & $(2)$ \\
\hline age & No organization & Large organization \\
male & -0.011 & 0.046 \\
& $(0.013)$ & $(0.042)$ \\
household size & 0.068 & -0.587 \\
& $(0.613)$ & $(1.251)$ \\
unmarried & 0.357 & 0.409 \\
& $(0.363)$ & $(0.912)$ \\
no religion & $-1.008^{*}$ & 1.227 \\
& $(0.559)$ & $(1.386)$ \\
left party & -0.571 & -3.242 \\
& $(1.169)$ & $(2.679)$ \\
education & -3.119 & -5.259 \\
& $(2.902)$ & $(4.168)$ \\
income & -1.155 & 1.239 \\
& $(0.708)$ & $(1.573)$ \\
No. of observations & -0.649 & $(1.666)$ \\
Wald test: Prob $>$ chi2 $=0.5375$ & $(0.781)$ & 279 \\
LR test for IIA: Prob $>$ chi2 $=0.0931$ & 279 & \\
\hline Notes: base variable: small organization. & & \\
Standard errors in parentheses. & & \\
Levels of significance: $*$ p $<0.10, * * \mathrm{p}<0.05, * * * \mathrm{p}<0.01$. & \\
\end{tabular}

\section{Conclusions}

The results of our experiment contribute to understanding how the provision of information about charities' revenues affects individual donation decisions. We find that subjects prefer to give to small charities with relatively low revenues as compared to large charities. Thus, our results support the predictions that may be derived from the model of impact philanthropy by Duncan (2004), which assumes that donors try to achieve the biggest impact possible with their charitable contribution, as well as from the public goods model, which predicts incomplete crowding out of voluntary contributions by third party contributions. Our survey data shows that quality considerations as suggested by Vesterlund (2003) and Andreoni (2006) play a role for those few donors that chose to give to large organizations.

The type of information we announced in our experiment differs from that used in other experiments: To our knowledge, this is the first study which provides participants with the information about a charity's entire revenues. We deem this kind of information to be more realistic because in real-life donation decisions, individuals usually do not precisely know whether and how much other individuals have given and to which extent a charity is subsidized by government. While the announcement of other individuals' contributions is likely to lead to the emergence of anchor points or the desire to comply with own or others' 
expectations, the information provided in our experiment does not point in one specific direction but rather offers two charities of different size. Considerations like signaling of wealth (Glazer and Konrad, 1996) or social approval (Holländer, 1990) are not relevant in our anonymous setting. Thus, varying the content of (social) information can be a fruitful area of further research.

The results of our experiment confirm previous findings that the individual willingness to donate increases with subjects' age, income, and education (e.g. Pharoah and Tanner, 1997, Schervish and Havens, 1997). This suggests that donation decisions in our experiment are a good indicator of real-life decisions. Unmarried individuals donate significantly more and voters of the left party donate significantly less than others. As individuals with certain characteristics are more likely to react positively when provided with the opportunity to make a donation, fundraisers may be able to increase donations by specifically targeting those individuals. 


\section{References}

Andreoni, J. (1989), Giving With Impure Altruism: Applications to Charity and Ricardian Equivalence, Journal of Political Economy 97, 1447-1458.

Andreoni, J. (1990), Impure Altruism and Donations to Public Goods: A Theory of WarmGlow Giving, Economic Journal 100, 464-477.

Andreoni, J. (1993), An Experimental Test of the Public-Goods Crowding-Out Hypothesis, American Economic Review 83, 1317-1327.

Andreoni, J. (1998), Toward a Theory of Charitable Fund-Raising, Journal of Political Economy 106, 1186-1213.

Andreoni, J. (2006), Leadership Giving in Charitable Fund-Raising, Journal of Public Economic Theory 8, 1-22.

Andreoni, J. and A.A. Payne (2009), Is Crowding Out Due Entirely to Fundraising? Evidence from a Panel of Charities, mimeo.

Andreoni, J. and R. Petrie (2004), Public Goods Experiments without Confidentiality: A Glimpse into Fund-Raising, Journal of Public Economics 88, 1605-1623.

Arulampalam, W., P. G. Backus and J. Micklewright (2009), Donations for Overseas Development: Evidence from a Panel of UK Charities, S3RI Applications \& Policy Working Papers, A09/02.

Bergstrom, T., L. Blume and H. Varian (1986), On the Private Provision of Public Goods, Journal of Public Economics 29, 25-49.

Bolton, G.E. and E. Katok (1998), An Experimental Test of the Crowding Out Hypothesis: The Nature of Beneficent Behavior, Journal of Economic Behavior and Organization 37, 315-331.

Carpenter, J., C. Connolly and C. K. Myers (2008), Altruistic Behavior in a Representative Dictator Experiment, Experimental Economics 11, 282-298.

Chan, K.S., R. Godby, S. Mestelman and R.A. Muller (2002), Crowding-Out Voluntary Contributions to Public Goods, Journal of Economic Behavior and Organization 48, 305-317.

Corneo, G. and H. P. Grüner (2002), Individual Preferences for Political Redistribution, Journal of Public Economics 83, 83-107.

Croson, R. and J. Shang (2008), The Impact of Downward Social Information on Contribution Decisions, Experimental Economics 11, 221-233.

Croson, R. and J. Shang (2010), Limits of the Effect of Social Information on the Voluntary Provision of Public Goods: Evidence from Field Experiments, mimeo.

Duncan, B. (2004), A Theory of Impact Philanthropy, Journal of Public Economics 88, 21592180 .

Eckel, C.C., P.J. Grossman and R.M. Johnston (2005), An Experimental Test of the Crowding Out Hypothesis, Journal of Public Economics 89, 1543-1560. 
Fischbacher, U., S. Gächter and E. Fehr (2001), Are People Conditionally Cooperative? Evidence from a Public Goods Experiment, Economics Letters 71, 397-404.

Frey, B.S. and S. Meier (2004), Social Comparisons and Pro-Social Behavior: Testing "Conditional Cooperation" in a Field Experiment, American Economic Review 94, 1717-1722.

Glazer, A. and K.A. Konrad (1996), A Signaling Explanation for Charity, American Economic Review 86, 1019-1028.

Gruber, J. and D.M. Hungerman (2007), Faith-Based Charity and Crowd-Out During the Great Depression, Journal of Public Economics 91, 1043-1069.

Harrison, G. W. and J. A. List (2004), Field Experiments, Journal of Economic Literature 42, 1009-1055.

Hoffman, E., K. McCabe, K. Shachat and V. Smith (1994), Preferences, Property Rights, and Anonymity in Bargaining Games, Games and Economic Behavior 7, 346-380.

Holländer, H. (1990), A Social Exchange Approach to Voluntary Cooperation, American Economic Review 80, 1157-1167.

Khanna, J., J. Posnett and T. Sandler (1995), Charity Donations in the UK: New Evidence Based on Panel Data, Journal of Public Economics 56, 257-272.

Khanna, J. and T. Sandler (2000), Partners in Giving: The Crowding-In Effects of UK Government Grants, European Economic Review 44, 1543-1556.

Konow, J. (2010), Mixed Feelings: Theories of and Evidence on Giving, Journal of Public Economics 94, 279-297.

Landry, C.E., A. Lange, J.A. List, M.K. Price and N.G. Rupp (2006), Toward an Understanding of the Economics of Charity: Evidence from a Field Experiment, Quarterly Journal of Economics 121, 747-782.

List, J.A. and D. Lucking-Reiley (2002), The Effects of Seed Money and Refunds on Charitable Giving: Experimental Evidence from a University Capital Campaign, Journal of Political Economy 110, 215-233.

Martin, R. and J. Randal (2008), How is Donation Behaviour Affected by the Donations of Others?, Journal of Economic Behavior \& Organization 67, 228-238.

Payne, A.A. (2001), Measuring the Effect of Federal Research Funding on Private Donations at Research Universities: Is Federal Research Funding More than a Substitute for Private Donations?, International Tax and Public Finance 8, 731-751.

Pharoah, C. and S. Tanner (1997), Trends in Charitable Giving, Fiscal Studies 18, 427-443.

Ribar, D.C. and M.O. Wilhelm (2002), Altruistic and Joy-of-Giving Motivations in Charitable Behavior, Journal of Political Economy 110, 425-457.

Roberts, R.D. (1984), A Positive Model of Private Charity and Public Transfers, Journal of Political Economy 92, 136-148.

Rondeau D. and J.A. List (2008), Matching and Challenge Gifts to Charity: Evidence from Laboratory and Natural Field Experiments, Experimental Economics 11, 253-267.

Schervish, P.G. and J. J. Havens (1997), Social Participation and Charitable Giving: A Multivariate Analysis, Voluntas 8, 235-260. 
Shang, J. and R. Croson (2009), A Field Experiment in Charitable Contribution: The Impact of Social Information on the Voluntary Provision of Public Goods, Economic Journal $119,1422-1439$.

Soetevent, A. R. (2005), Anonymity in Giving in a Natural Context - A Field Experiment in 30 Churches, Journal of Public Economics 89, 2301-2323.

Steinberg, R. (1987), Voluntary Donations and Public Expenditures in a Federalist System, American Economic Review 77, 24-36.

Steinberg, R. (1991), Does Government Spending Crowd Out Donations? Interpreting the Evidence, Annals of Public and Cooperative Economics 62, 591-617.

Vesterlund, L. (2003), The Informational Value of Sequential Fundraising, Journal of Public Economics 87, 627-657.

Warr, P.G. (1982), Pareto Optimal Redistribution and Private Charity, Journal of Public Economics 19, 131-138. 


\section{Appendix}

\section{Appendix A: Tables and Figures}

Table A1: Socio-demographic characteristics of participants - Part I

\begin{tabular}{|c|c|c|c|}
\hline Variable & State & Frequency abs. & Frequency in $\%$ \\
\hline \multirow[t]{3}{*}{ Gender } & Male & 103 & 46.19 \\
\hline & Female & 119 & 53.36 \\
\hline & No answer & 1 & 0.45 \\
\hline \multirow[t]{5}{*}{ Age } & $18-29$ & 73 & 32.74 \\
\hline & $30-44$ & 60 & 26.91 \\
\hline & $45-59$ & 54 & 24.22 \\
\hline & $60-75$ & 34 & 15.25 \\
\hline & No answer & 2 & 0.90 \\
\hline \multirow[t]{5}{*}{ Family Status } & Single & 139 & 62.33 \\
\hline & Married & 45 & 20.18 \\
\hline & Divorced & 31 & 13.90 \\
\hline & Widowed & 6 & 2.69 \\
\hline & No answer & 2 & 0.90 \\
\hline \multirow[t]{2}{*}{ Children } & Yes & 34 & 15.25 \\
\hline & No & 189 & 84.75 \\
\hline \multirow{5}{*}{$\begin{array}{l}\text { Household } \\
\text { size }\end{array}$} & 1 & 102 & 45.74 \\
\hline & 2 & 82 & 36.77 \\
\hline & 3 & 21 & 9.42 \\
\hline & 4 or more & 17 & 7.62 \\
\hline & No answer & 1 & 0.45 \\
\hline \multirow[t]{6}{*}{ Education } & University & 88 & 39.46 \\
\hline & Gymnasium (12 years of education) & 58 & 26.01 \\
\hline & Realschule (10 years of education) & 35 & 15.70 \\
\hline & Hauptschule (9 years of education) & 23 & 10.31 \\
\hline & Other & 17 & 7.62 \\
\hline & No graduation & 2 & 0.90 \\
\hline \multirow[t]{7}{*}{ Nationality } & German & 192 & 86.10 \\
\hline & Turkish & 2 & 0.90 \\
\hline & Italian & 3 & 1.35 \\
\hline & Polish & 2 & 0.90 \\
\hline & Other & 23 & 10.31 \\
\hline & No answer & 1 & 0.45 \\
\hline & $\sum$ & 223 & 100.00 \\
\hline
\end{tabular}


Table A2: Socio-demographic characteristics of participants - Part II

\begin{tabular}{llcc}
\hline Variable & State & Frequency abs. & Frequency in \% \\
\hline Household net & $<1,000 €$ & 51 & 22.87 \\
income & $1,000-2,000 €$ & 85 & 38.12 \\
& $2,000-3,000 €$ & 44 & 19.73 \\
& $3,000-4,000 €$ & 13 & 5.83 \\
& $4,000-5,000 €$ & 8 & 3.59 \\
& $>5,000 €$ & 8 & 3.59 \\
Religion & No Answer & 14 & 6.28 \\
\cline { 2 - 4 } & Catholic & 70 & 31.39 \\
& Evangelic & 71 & 31.84 \\
& Muslim & 5 & 2.24 \\
& Other & 10 & 4.48 \\
Voting & No religion & 67 & 30.04 \\
\cline { 2 - 4 } behavior & The Christian Democratic / Christian & 43 & 19.28 \\
& Social Union & & \\
& The Social Democratic Party & 49 & 21.97 \\
& The Greens & 42 & 18.83 \\
& The Free Democratic Party & 25 & 11.21 \\
& The Left Party & 17 & 7.62 \\
& Other & 9 & 4.04 \\
& Nonvoter & 17 & 7.62 \\
& No answer & 21 & 9.42 \\
\cline { 2 - 4 } & $\Sigma$ & 223 & 100.00 \\
\hline
\end{tabular}

Table A3: Charitable giving habits of participants

\begin{tabular}{|c|c|c|c|}
\hline Variable & State & Frequency abs. & Frequency in $\%$ \\
\hline \multirow[t]{2}{*}{ Donated before } & Yes & 189 & 84.75 \\
\hline & No & 34 & 15.25 \\
\hline \multirow{11}{*}{$\begin{array}{l}\text { Modal charitable } \\
\text { purpose }^{1}\end{array}$} & Child or disabled care & 46 & 20.63 \\
\hline & Emergency aid & 12 & 5.38 \\
\hline & Medical research & 13 & 5.83 \\
\hline & Church and religious purposes & 11 & 4.93 \\
\hline & Environment or animal protection & 32 & 14.35 \\
\hline & Development aid & 39 & 17.49 \\
\hline & $\begin{array}{l}\text { General (e.g. Red Cross, } \\
\text { charitable lotteries) }\end{array}$ & 20 & 8.97 \\
\hline & Culture & 3 & 1.35 \\
\hline & Politics & 2 & 0.90 \\
\hline & $\begin{array}{l}\text { Local welfare services, homeless } \\
\text { persons, poverty }\end{array}$ & 8 & 3.59 \\
\hline & $\begin{array}{l}\text { No answer (incl. } 34 \text { subjects who } \\
\text { did not donate before) }\end{array}$ & 37 & 16.59 \\
\hline \multirow{5}{*}{$\begin{array}{l}\text { Contribution } \\
\text { receipt received }\end{array}$} & Always & 60 & 26.91 \\
\hline & Mostly & 36 & 16.14 \\
\hline & Sometimes & 42 & 18.83 \\
\hline & Never & 49 & 21.97 \\
\hline & $\begin{array}{l}\text { No answer (incl. } 34 \text { subjects who } \\
\text { did not donate before) }\end{array}$ & 36 & 16.14 \\
\hline \multirow[t]{3}{*}{ Donated in 2009} & Yes & 67 & 30.04 \\
\hline & No & 156 & 69.96 \\
\hline & $\sum$ & 223 & 100.00 \\
\hline
\end{tabular}

1 If subjects stated that they have donated before they were asked to which charity they donated most frequently. If subjects gave more than one answer the charity named first was included. 
Table A4: Attitudes of participants towards society and government responsibilities

\begin{tabular}{llrr}
\hline Question / Statement & Answer & Frequency abs. & Frequency in \% \\
\hline Compared with how others live in & Very much less & 20 & 8.97 \\
Germany: Do you think you get & Somewhat less & 61 & 27.36 \\
your fair share, more than your fair & Fair share & 104 & 46.64 \\
share, somewhat less or very much & More than fair share & 19 & 8.52 \\
less than your fair share? & Don't know & 19 & 8.52 \\
\cline { 2 - 4 } All in all, I think the social & Completely agree & 14 & 6.28 \\
differences in this country are just. & Tend to agree & 65 & 29.15 \\
& Tend to disagree & 90 & 40.36 \\
& Completely disagree & 50 & 22.42 \\
It is the responsibility of the state & Don't know & 4 & 1.79 \\
\cline { 2 - 4 } to meet everyone's needs, even in & Completely agree & 74 & 33.18 \\
case of sickness, poverty, & Tend to agree & 104 & 46.64 \\
unemployment and old age. & Comd to disagree & 35 & 15.70 \\
& Completely disagree & 4 & 1.79 \\
It is the responsibility of the & Don't know & 6 & 2.69 \\
\cline { 2 - 4 } government to reduce the & Strongly agree & 32 & 14.35 \\
differences in income between & Ngree & 73 & 32.74 \\
people with high incomes and & Neither agree nor disagree & 39 & 17.49 \\
those with low incomes. & Disagree & 48 & 21.52 \\
& Strongly disagree & 17 & 7.62 \\
\hline & Can't choose, don't know & 14 & 6.28 \\
\hline
\end{tabular}

\section{Figure A1: Proceedings of the experiment}

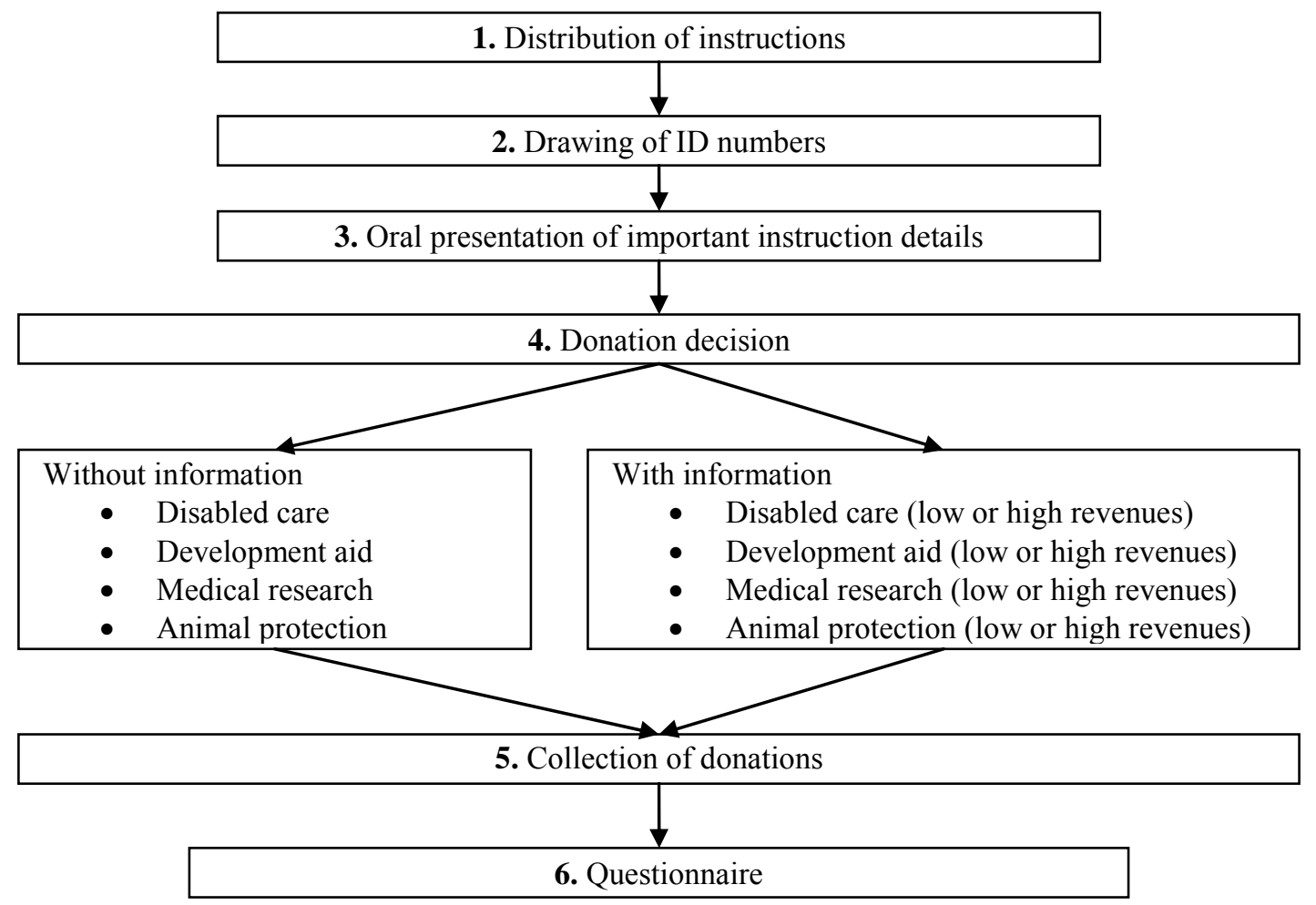

Note: The treatments with information are identical to the treatments without information except for the fact that in the donation stage subjects could choose between a small organization (with revenues between $€ 40,000$ and $€ 300,000$ ) and a large organization (with revenues between $€ 5$ million and $€ 11$ million) for each charitable purpose. 


\section{Appendix B: Experimental Instructions (translated from German)}

\section{Welcome!}

Thank you very much for participating in our study for the analysis of consumer behavior. Enclosed in this folder, you find information which you need during this event. You may return pages to which you have already gone through at any time. Please turn pages only up to the next "stop-sign". You will be asked to turn to the next page. Please only read the respective text and do not act until you receive specific instructions to follow the assignment.

Please follow the instructions carefully. We also would like to ask you not to talk to other participants.

We want to emphasize that all information which we gain from today's event will only be used to draw a comparison between the groups of participants. No individual data about the participants will be published or passed on.

Shortly, we will come up to your seat and you will draw a piece of paper with a number on it. This number will serve as your personal identification number (ID) throughout the study. Please state your ID whenever you are asked to do so during the study. The ID ensures anonymity, as neither other participants nor we know your name or the ID that belongs to it.

-- STOP sign : Please do not turn the page until we ask you to! --

\section{Part 1}

For your participation in the study, you will receive 40 Euros. Shortly, we will hand out the money in an envelope. Then we ask you to confirm the receipt. Afterwards, you will get the opportunity to donate any preferred amount of money to a charitable cause.

There is a charitable organization behind every charitable cause. The money which you, if any, will donate, will be completely transferred to the respective charity. We guarantee that this will happen lawfully and will have the transfer supervised and verified by the director of the notary's office, Dr. Rainer Preusche.

All selected charitable organizations hold the "donation seal" by the state-approved German Central Institute for Social Issues (Deutsches Zentralinstitut für soziale Fragen (DZI)). This assures that the organizations act autonomously and charitably and that the usage of their financial means is reviewable, economical and statutory. The names of the individual organizations will at this point - for scientific reasons - not be mentioned. We guarantee that all information you receive from us regarding the organizations is true. At the end of the experiment, we are happy to hand to you a list of all organizations upon request.

Following, we present to you four different charitable causes to which you can donate in the course of this study.

The four charitable causes are:

- Medical research

- Animal protection

- Disabled care

- Development aid 
[Additional part mentioned only in the Info Treatment:

The organizations you can make a donation to do not only differ with regard to their charitable causes, but also their revenues, which these organizations have generated in 2006 from donations, membership fees and government grants. For each charitable cause, we offer you a charitable organization with relatively small revenues between 40,000 and 300,000 Euros and organizations with rather large revenues between 5 million Euros and 11 million Euros.

Therefore, we ask you, in the case you donate, to pick one of the following organizations:

a. Medical research Revenues 2006: 40,000€-300,000€

b. Medical research Revenues 2006: 5 Mio. $€-11$ Mio. $€$

c. Animal protection Revenues 2006: 40,000€ - 300,000€

d. Animal protection Revenues 2006: 5 Mio. $€$ - 11 Mio. $€$

e. Disabled care $\quad$ Revenues 2006: 40,000€ - 300,000€

f. Disabled care $\quad$ Revenues 2006: 5 Mio. $€-11$ Mio. $€$

g. Development aid Revenues 2006: 40,000€-300,000€

h. Development aid Revenues 2006: 5 Mio. €-11 Mio. €]

We now hand out to you an envelope with the money you receive for your participation in our study.

-- STOP sign : Please do not turn the page until we ask you to! --

In the envelope, you find:

- one white envelope

- one blue envelope

- 40 Euros, composed of two 10 Euro-bills, one 5 Euro-bill, six 2 Eurocoins and three 1 Euro-coins

- one receipt.

We now ask you to sign the receipt you find enclosed. By doing so, you confirm that you have received 40 Euros from $\mathrm{ZEW}$ for the participation in this study. We need the receipt for administrative purposes. Without a receipt we are not allowed to give you the money. Your data is still handled confidentially and anonymized. We will now collect the receipts, the study will continue hereafter.

-- STOP sign : Please do not turn the page until we ask you to! --

Now you can make a donation decision. You can decide freely and anonymously whether and how much money you want to give to one of the above-mentioned charitable organizations. The amount of money you put into the blue envelope will benefit a charitable 
cause and will be transferred completely to the respective charity after the experiment. You will keep the amount of money you put into the white envelope.

The study proceeds as follows:

1.) Make your donation decision.

In case of a donation, please tick the desired charitable organization on the blue envelope. Please note that you have to choose one of the four [in the Info treatment: eight] charities given. It is not possible to choose more than one charitable organization for your donation. Please tick only one organization if you wish to donate. If you tick more than one organization, unfortunately, we will not be able to transfer the donation. If you do not wish to donate, please do not tick any organization.

2.) Write down your ID-number into the predefined box on the blue envelope, irrespective of whether you wish to donate or not.

3.) Put the desired donation amount into the blue envelope.

4.) Put the amount of money you wish to keep into the white envelope.

Finally, you should have distributed 40 Euros completely to the two envelopes. Please note that any distribution in full amounts of Euros is possible. You may put any desired amount of money into both envelopes. It is also possible to put 40 Euros completely into one envelope.

5.) Seal up both envelopes.

When all participants have finished, we will come up to you and collect the blue envelope. When we do so, please put the blue envelope into the box. Please keep the white envelope. We guarantee that your donation will be transferred to the charitable organization lawfully and have the transfer supervised and verified by the director of the notary's office, Dr. Rainer Preusche.

We will explain the most important items once again orally. Afterwards, please make your decision as described above.

-- STOP sign : Please do not turn the page until we ask you to! --

\section{Part 2 - Questionnaire}

Please answer the following questions by ticking or filling out.

If you have a question, please raise your hand. We will come up to you and answer your question. Please do not say your question out loud and please do not talk to other participants.

1. What is your ID-number?

2. How can your marital status be described?

$\mathrm{O}$ unmarried 

O married
O divorced
$\mathrm{O} \quad$ widowed

3. Please state your gender:
$\mathrm{O}$ male
O female

4. What is your year of birth?

5. How many people, including you, live in your household?

6. How many children live in your household?
O $\quad 0-3$ years old
O 4-7 years old
O 8-12 years old
O $\quad 13-18$ years old
O older than 18 years
$\mathrm{O}$ none

7. What is your religious affiliation?
O Catholic
O Protestant
O Muslim
O Jewish
O Buddhist
O other:
$\mathrm{O}$ no religion

8. What is your highest educational achievement?
O University/College
$\mathrm{O}$ higher education entrance qualification
O middle school
O secondary modern school
O other: 
O none

9. What is your original nationality?
O German
O Turkish
O Italian
O Polish
O other:

10. What is your first language?

11. What are the monthly net earnings of your household (how much money per month is available for your household altogether?)
O below 1,000 Euros
O $\quad 1,000-2,000$ Euros
O 2,000-3,000 Euros
O $3,000-4,000$ Euros
O $\quad 4,000-5,000$ Euros
O above 5,000 Euros
O not specified

12. Which party would you vote for if there were federal elections on the coming Sunday?
$\mathrm{O} \quad \mathrm{CDU} / \mathrm{CSU}$
$\mathrm{O} \quad \mathrm{SPD}$
O Bündnis 90 / The Green Party
O FDP
O The Left
O Other
O I do not vote
O not specified

14. Have you made a donation to a charitable organization before?
$\mathrm{O}$ yes
O no

15. To which purpose have you to date donated most often? 
16. Have you already donated this year to a charitable organization?
$\mathrm{O}$ yes
O no

17. If you answered question 16 with "yes", in which month have you donated last?

18. If you answered question 16 with "yes", how much have you donated this year altogether? $€$

19. Have you ever received a donation receipt for your donation?
O always
O mostly
O occasionally
$\mathrm{O}$ never

20. Compared with how others live in Germany: Do you think you get your fair share, more than your fair share, somewhat less or very much less than your fair share?
O fair share
O more than fair share
O somewhat less than fair share
O very much less than fair share
O don't know

21. On the whole, I find the social differences in our country just.
O Completely agree.
O Tend to agree.
O Tend to disagree.
O Completely disagree.
O Don't know

22. The State must ensure that people can live a decent income even in illness, hardship, unemployment and old age.
O Completely agree.
O Tend to agree.
O Tend to disagree. 
O Completely disagree.

O Don't know

23. It is the responsibility of the government to reduce the differences in income between people with high incomes and those with low incomes.
O Agree strongly.
O Agree.
O Neither agree nor disagree.
O Disagree.
O Disagree strongly.
O Can't choose.

-- STOP sign : Please do not turn the page until we ask you to! --

We would like to ask you to write down general comments regarding our study. You may also give reasons for your donation decision. [11 empty lines follow]

We would like to thank you for participating in our study and wish you a nice day! Please remember to take the white envelope with you. 


\section{Appendix C: Invitation letter used for recruitment of participants (translated from German)}

The following writing was sent via private carriers to randomly selected households in the municipal area of Mannheim. The front page shows the logo of ZEW at the top of the letter, general contact information of the project manager and the following text:

\section{Ref.: Invitation to a scientific study on consumer behavior}

Dear Sir or dear Madam,

the Centre for European Economic Research (ZEW) Mannheim is a non-profit-making research institute, which is active in the field of applied economics. At present, ZEW is conducting a scientific study in the range of individual consumption decisions. In order to carry out our scientific study, we are looking for participants. For this reason, we would like to invite you.

For your participation in the study, which lasts about $\underline{60 \text { minutes, you will receive } \underline{40} \text { Euros }}$ in cash. With the money, you will be able to make consumption decisions during the study. The money spent will be subtracted from the 40 Euros you received. If you do not spend any money, you will be paid out 40 Euros without deductions. In doing so, your decisions will be voluntary and anonymous at all times. Only the ZEW researcher team will know your identity, your statements will be treated with the utmost discretion and according to the Data Protection Act.

Please consider the following requirements for the participation in the study:

- registration by phone,

- residence in Mannheim (verification with, for example, your identity card),

- very good knowledge of the German language,

- $\quad$ between 18 and 75 years old

- arriving on time on the selected date and presenting this letter

If you would like to take part in the study and meet the conditions mentioned above, please choose one of the dates listed on the next page and register by telephone. The selection of participants is carried out according to scientific criteria. The event will be taking place at the ZEW. At the end of the event, you will receive 40 Euros in cash minus the amount which you have possibly spent for your personal consumption. Should you have any further questions, please do not hesitate to call us at $0621 / 1235-395$ from June $29^{\text {th }}$ to July $15^{\text {th }} 2009$, $4 \mathrm{pm}$ to $6 \mathrm{pm}$.

We are looking forward to welcoming you as participants in our study.

Yours sincerely,

Sarah Borgloh (project manager)

The back page offers further information concerning the study: 


\section{Registration:}

Please call from $\underline{\text { June } 29^{\text {th }}}$ to July $15^{\text {th }} 2009$ (Monday to Friday) between 4 pm and 6 pm at the following number: 0621/1235-395. Please state the date (see below) that you want to participate at. For the registration, your name will be noted, however, as explained above, will not be published or given to a third party. Please take note that with the receipt of this letter, you do not have any claim to participate. The selection of participants will be carried out according to scientific criteria.

\section{Dates (day, date, time):}

Sat, July $18^{\text {th }} 2009$, 9-10am Tue, July $21^{\text {st }} 2009$, 9-10am

Sat, July $18^{\text {th }} 2009,11-12$ am Tue, July $21^{\text {st }} 2009$, 5-6pm

Sat, July $18^{\text {th }} 2009,2-3 \mathrm{pm} \quad$ Tue, July $21^{\text {st }} 2009,7-8 \mathrm{pm}$

Mon, July $20^{\text {th }} 2009,9-10 \mathrm{am} \quad$ Wed, July $22^{\text {nd }} 2009$, 9-10am

Mon, July $20^{\text {th }} 2009,5-6 \mathrm{pm} \quad$ Wed, July $22^{\text {nd }} 2009,5-6 \mathrm{pm}$

Mon, July $20^{\text {th }} 2009,7-8 \mathrm{pm} \quad$ Wed, July $22^{\text {nd }} 2009,7-8 \mathrm{pm}$

It follows a map of the location of ZEW and general information about the ZEW taken from the homepage of ZEW, www.zew.de. 